\title{
Perancangan dan Implementasi Sistem Keamanan Jaringan Komputer Menggunakan Metode Port Knocking Pada Sistem Operasi Linux
}

\author{
Imam Marzuki \\ Program Studi Teknik Elektro, Fakultas Teknik \\ Universitas Panca Marga Probolinggo \\ J1. Yos Sudarso, Pabean, Dringu, Kab. Probolinggo 67271 \\ imam@upm.ac.id
}

\begin{abstract}
Keamanan suatu server merupakan salah satu hal yang penting bagi seorang administrator. Tentunya seorang administrator adalah orang yang berhak untuk mengakses server. Apabila ada actacker yang mengambil alih posisi administrator, maka sistem dikatakan tidak aman. Pada penelitian ini difokuskan pada sistem keamanan pada server dari serangan attacker yang ingin merubah dan merusak suatu server. Studi kasus pada penelitian ini adalah ssh server yang berjalan di port 22. Hal ini dikarenakan layanan ssh yang paling banyak diincar oleh attacker. Metode keamanan yang digunakan dalam penelitian ini adalah port knocking. Dengan menggunakan metode port knocking seorang administrator dapat meningkatkan keamanan suatu server dari berbagai seranagn yang ditujukan utuk layanan server. Cara kerja dari metode ini adalah server akan menerima percobaa koneksi dari client menuju port yang sudah ditentukan setelah itu firewall akan mendeteksi percobaan tersebut dan mengizinkan client untukmengakses server. Setelah client selesai mengakses serverfirewall akan menutup kembali akses ke server sehingga server tidak bisa di akses kembali. Dalam penelitian ini server berhasil melindungi layanan yang ada dengan megintegrasikan aturan firewall dengan program port knocking yang digunakan. Selain itu tanpa mengirimkan ketukan yang tepat, client tidak dapat menggunakan layanan pada server.
\end{abstract}

Kata kunci : server, metode port knocking, administrator, keamanan

\section{PENDAHULUAN}

Kemajuan teknologi di bidang jaringan telah memungkinkan untuk melakukan interaksi melalui komputer. Suatu jaringan komputer biasanya terdiri dari server dan client. Server dikendalikan oleh seorang administrator. Salah satunya dengan melakukan remote server. Administrator yang meremote suatu server haruslah orang yang berhak untuk mengakses server tersebut. Namun ada juga attacker yang dengan sengaja masuk kedalam sistem dan kemudian melakukan perubahan serta pengrusakan terhadap server.
Salah satu upaya yang dilakukan untuk meningkatkan keamanan sebuah server adalah dengan menggunakan firewall. Tetapi saat ini masih memiliki kelemahan. firewall tidak mampu membedakan user yang dapat dipercaya.Firewall hanya mampu membedakan alamat IP yang diasumsikan digunakan oleh orang yang tidak dapat dipercaya. Sehingga dicari solusi untuk mengurangi kelemahan yang ada. metode ini salah satunya adalah dengan menggunakan metode port knocking.

\section{METODE PENELITIAN}

\subsection{Tahapan Penelitian}

Tahapan penelitian ditunjukkan dengan flowchart pada gambar 1.

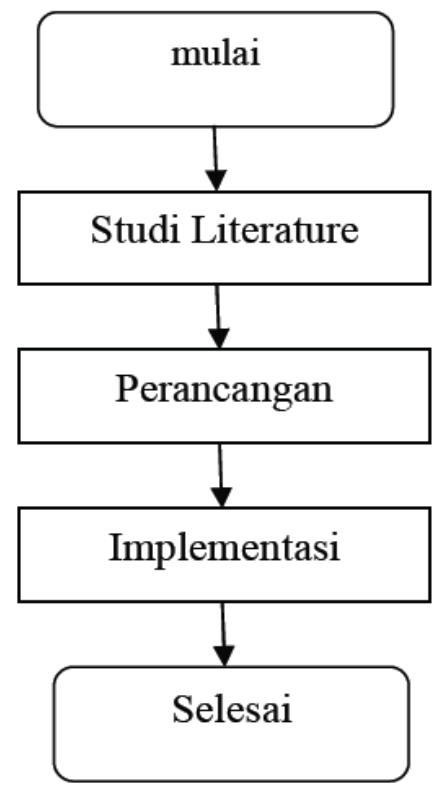

Gambar 1. Flowchart tahapan penelitian

\section{1.1 Studi Literatur}

Pencarian referensi dan sumber-sumber yang dapat digunakan sebagai acuan dalam pembuatan penelitian ini 
serta teori-teori dasar lain mengenai perancangan dan implementasi metode port knocking pada linux ubuntu.

\subsubsection{Perancangan}

Merancang suatu system yang mampu melakukan koneksi melalui port yang tertutup menggunakan metode port knocking.

\subsubsection{Implementasi}

Bagaimana mengimplementasikan metode port knocking umtuk dapa mengamankan layanan server (studi kasus ssh server).

\section{2 Konfigurasi IPTABLES}

Pada IPTABLES di Linux sudah terinstall secara default dimana IPTABLES merupakan firewall di sistem operasi linux. Dalam konsep port knocking, IPTABLES difungsikan untuk menutup atau DROP semua akses yang menuju port 22. Untuk perintah yang dilakukan untuk $D R O P$ akses port 22 dengan menulis perintah IPTABLES $-A$ INPUT $-p$ tcp -dport $22-j D R O P$ dan untuk melihat aturan tersebut sudah tersimpan dengan perintah IPTABLES $-L$ pada terminal console dan dapat dilihat hasilnya seperti pada gambar 2 .

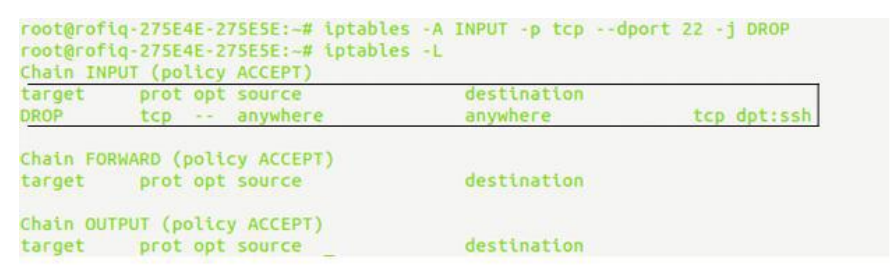

Gambar 2. Drop Port 22 IPTABLES

\subsection{Diagram Topologi Jaringan}

Dalam perancangan Diagram Topologi jaringan penelitian ini menggunakan dua buah komputer, satu laptop sebagai administrator client server yaitu komputer yang akan mengakses atau meremote server melalui port 22 server menggunakan system operasi linux ubuntu. Diagram topologi jaringan ditunjukkan pada gambar 3 .

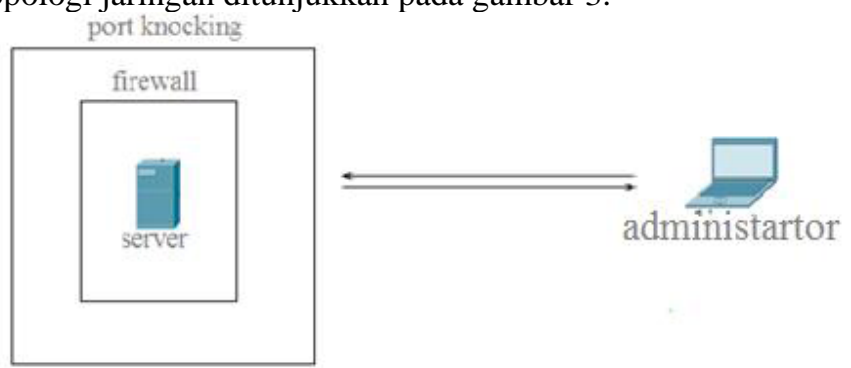

Gambar 3. Diagram topologi jaringan

Semua koneksi ke server akan ditutup oleh firewall, Dikarernakan ditutupnya semua koneksi administrator tidak bisa melakukan koneksi ke server. Jika administrator ingin meremote server administrator harus melakukan knocking ke server. Jika knocking yang dilakukan administrator sesuai dengan konfigurasi yang sudah di atur sebelumnya di server maka firewall akan mengizinkan administrator tersebut melakukan koneksi server menuju ke port 22.

\subsection{Perancangan Sistem}

2.3.1 Flowchart Aplikasi Port Knocking

Cara kerja aplikasi port knocking ditunjukkkan dengan flowchart pada gambar 4.

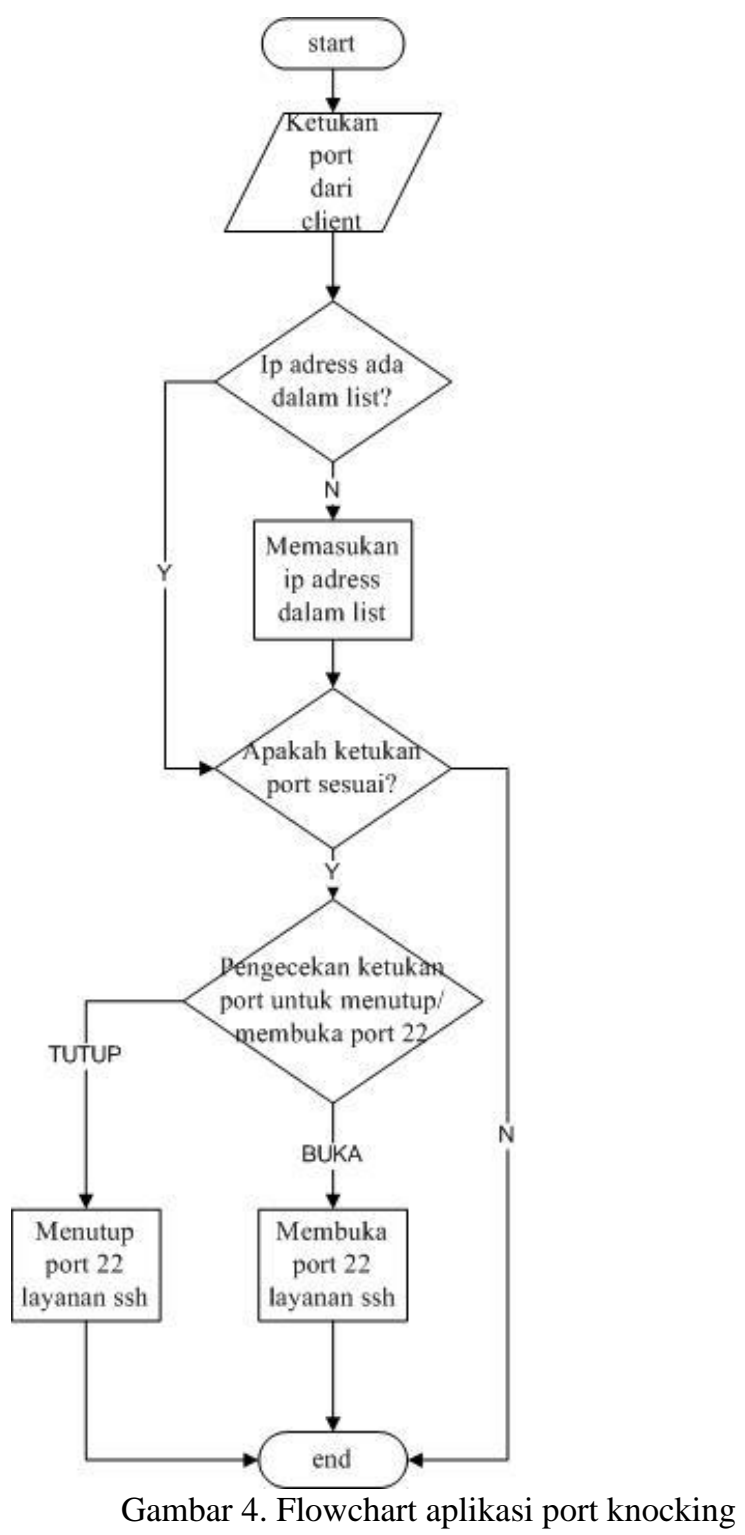

Gambaran alur proses dari flowchart aplikasi port knocking di jabarkan sebagai berikut:

1. Client melakukan ketukan port untuk membuka port 22

2. Apakah IP Address client berada dalam list firewall jika tidak memasukan IP Address client dalam list. 
3. Jika ketukan port dari client tidak sesuai maka client tidak diijinkan tetapi jika ketukan port sesuai maka client di ijinkan.

4. Setelah itu ketukan port dari client akan di cek oleh firewall, apakah ketukan tersebut membuka atau menutup port 22.

\subsubsection{Context Diagram}

CD memperlihatkan sistem yang di rancang secara keseluruhan, semua external entity harus digambarkan sedemikian rupa, sehingga terlihat data yang mengalir pada input-proses output.

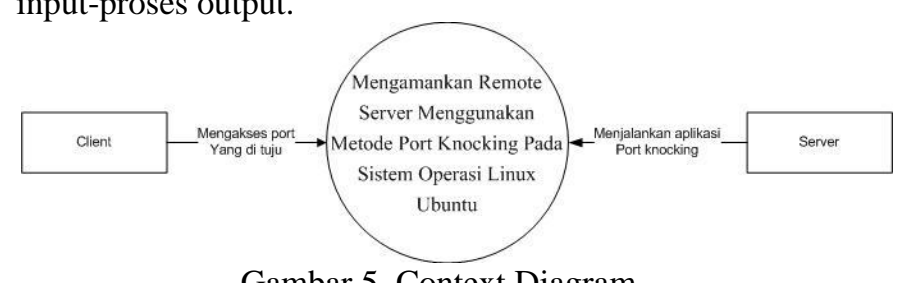

Gambar 5. Context Diagram

Gambar 5 menjabarkan proses client dan server dalam menjalakan atau menggunakan aplikasi port knocking. Di mana server menjalankan perintah untuk mengaktifkan apliksi port knocking, sedangkan client menjalankan perintah untuk mengakses port yang digunakan.

\subsubsection{Context Diagram}

Data Flow Diagram (DFD) memberikan gambaran komponen komponen dari sebuah sistem beserta aliran data. Data Flow Diagram (DFD) dapat dilihat pada gambar 6.

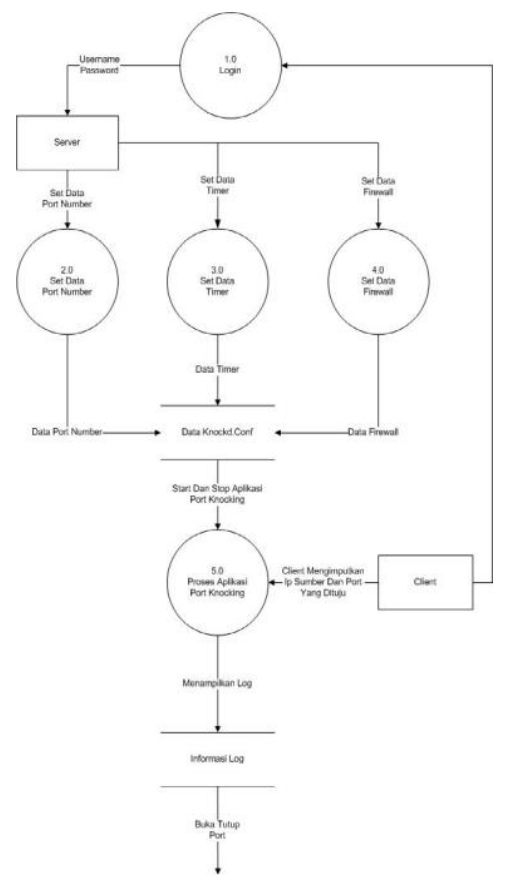

Gambar 7. Data Flow Diagram
Gambar 7 menjabarkan proses aplikasi port knocking. Server terlebih dahulu melakukan login kedalam sistem., kemudian server melakukan set data port number, timer, firewall didalam file knockd.conf. setelah data diset server menyimpan aplikasi port knocking dan menjalankan atau memberhentikan aplikasi port knocking. Client melakukan login kedalam sistem agar dapat menggunakan port yang ingin dituju. Client menjalankan perintah berdasarkan IP sumber dan Port Number untuk mengakses port yang digunakan dan Logs akan menampilkan informasi siapa yang masuk ke port yang dituju dan siapa yang menutup port yang dituju kedalam server.

\subsubsection{Format Ketukan Port Knocking}

Format ketukan yang digunakan dalam perancangan sistem adalah format port tunggal dengan pemetaan tetap, dan hanya menggunakan tiga port ketukan sebagai tujuan pengiriman paket data untuk melakukan ketukan.

Untuk mempermudah penentuan port ketukan, maka dibuat aturan pemilihan port ketukan sesuai dengan nomor port tujuan, digit terakhir pada nomor port ketukan merujuk pada nomor port tujuan. Sebagai contoh, seorang user ingin mengakses port 22 , dengan range port ketukan yang telah ditentukan yaitu antara port 300 sampai dengan 600 , maka pemilihan port ketukan yang digunakan adalah seperti pada Gambar 8.

\begin{tabular}{|c|c|}
\hline Nomor Port Ketukan & Port Tujuan \\
\hline $300+\mathrm{a}, 400+\mathrm{b}, 600+\mathrm{c}$ & $\mathrm{a}, \mathrm{b}, \mathrm{c}$ \\
\hline
\end{tabular}

Gambar 8. Penentuan format ketukan

Nomor port $300+a, 400+b, 600+c$ merupakan nomor port tujuan pengiriman paket data yang berfungsi sebagai port ketukan. Nomor port ketukan menunjukkan port tujuan abc yang akan dibuka atau ditutup. Maka ketukan yang dilakukan oleh pengguna jika ingin membuka 22 adalah seperti pada gambar 9 .

\section{$300,400,600$}

Gambar 9. Format ketukan membuka port 22

Sedangkan jika user ingin menutup port 22, maka ketukan yang dilakukan oleh client adalah seperti pada gambar 10 .

\section{$600,400,300$}

Gambar 10. Format ketukan menutup port 22 


\section{HASIL DAN PEMBAHASAN}

\subsection{Instalasi dan Konfigurasi Program}

Sebelum program port knocking di jalankan, pertama kali dilakukaninstalasi program pada komputer server yang berfungsi untuk mendengarkan ketukan port dari komputer client, Program port knocking yang di gunakan pada penelitian ini menggunakan aplikasi knockd yang yang ada pada setiap repository linux, Untuk menginstal aplikasi knockd harus terhubung ke internet tetapi dalam penelitian ini penulis menggunakan repository local dan hanya menghubungkan server ke repository tersebut, setelah terhubung instalasi aplikasi menggunakan "apt-get install knockd". Perintah yang dilakukan pada instalasi ini ditunjukan pada gambar 11 .

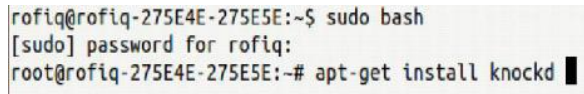

\section{Gambar 11. Perintah instalasi knockd}

Setelah instalasi selesai maka akan tercipta file knockd.conf. Selanjutnya adalah mengisi file knockd yang berada pada directory etc, Dengan beberapa baris text konfigurasi dengan menggunakan gedit sebagai medianya. Perintah yang dilakukan ditunjukan pada gambar 12 .

rofiq@rofiq-275E4E-275E5E: \$ sudo bash [sudo] password for rofiq: root@rofiq-275E4E-275E5E: \# gedit /etc/knockd.conf-

Gambar 12. Perintah knockd.conf

Setelah perintah diatas di jalankan maka akan menampilkan isi dari directory knockd.conf. beberapa baris text harus di masukan kedalam knockd.conf hasil perintah tersebut dapat dilihat pada gambar 13 .

\begin{aligned} & \hline [options] \\ & logfile $=/$ var $/ \log / \mathrm{knockd} . \log \\ &$ [openSSH] $= \\ &$ sequence $= \\ &$ seq_timeout $= \\ &$ command $= \\ &$ tcpflags $= \\ &$ [closesSH] $= \\ &$ sequence \\ & seq_timeout $= \\ &$ command $= \\ &$ tcpflags $= \\ &$ Gambar 13. File knockd kosong \end{aligned}

- Bagian option yang merupakan bagian yang berfungsi untuk menunjukan letak file log yang berfungsi untuk mencatat semua aktifitas port knocking.

- Seq_timeout pada [openSSH] berfungsi untuk menentukan batas waktu yang digunakan untuk melakukan pengiriman urutan port untuk membuka port tujuan dan Seq_timeout pada [closeSSH] berfungsi untuk menentukan batas waktu yang digunakan untuk melakukan pengiriman urutan port untuk menutup port tujuan.

- Command pada [openSSH] berfungsi untuk menentukan perintah IPTABLES yang dijalankan, yaitu perintah untuk membuka port tujuan jika terjadi pengiriman urutan port yang benar pada komputer server dan Command pada [closeSSH] berfungsi untuk menentukan perintah IPTABLES yang dijalankan, yaitu perintah untuk menutup port tujuan jika terjadi pengiriman urutan port pada komputer server.

- Tcpflag pada [openSSH] dan [closeSSH] samasama untuk menunjukan header paket yang dikirimkan sebagai urutan port

Untuk menentukan port ketukan, Maka di tambahkan baris perintah pada file knockd.conf, Seperti ditujukan pada gambar 14

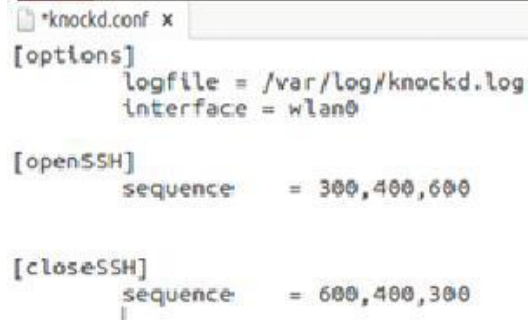

Gambar 14. Format ketukan

Pada bagian buka SSH di tentukan tiga nomor port ketukan, yaitu port 300 , port 400 , dan port 600 . Jika terjadi ketukan port pada ke tiga port tersebut secara berurutan, Maka server akan membuka port tujuan.

Pada bagian tutup SSH di tentukan tiga nomor port ketukan, yaitu port 600 , port 400 , dan port 300 . Jika terjadi ketukan port pada ke tiga port tersebut secara berurutan, Maka server akan menutup port tujuan.

Untuk menentukan perintah IPTABLES yang akan di jalankan jika terjadi ketukan port, maka ditambahkan baris perintah pada file knockd.conf. seperti ditunjukan pada gambar 15 .

Keterangan gambar 13 : 


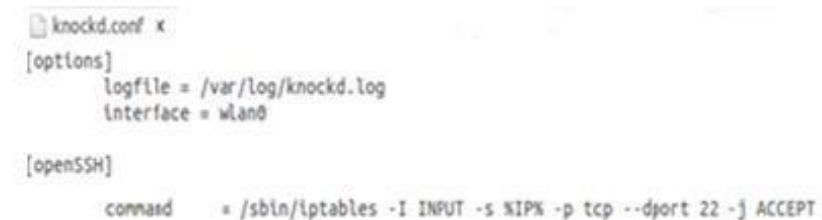

[closessh]

\section{comard $=/$ sbin/liptables - D INPUT - s XIPX $\rightarrow$ tCp - - dport 22 - 1 ACCEPT}

Gambar 15. Konfigurasi IPTABLES

Pada bagian buka SSH, Adalah perintah yang bertujuan untuk mengubah aturan pada IPTABLES, yaitu dengan membuka akses terhadap alamat IP komputer client agar dapat mengakses port 22 pada komputer server.

Pada bagian close SSH, Adalah perintah yang bertujuan untuk mengubah aturan pada IPTABLES, yaitu dengan menutup kembali akses terhadap alamat IP komputer client sehingga tidak dapat lagi mengakses port 22 pada komputer server.

Setelah konfigurasi selesai gambaran keseluruhan dari file knockd.conf dapat dilihat pada gambar 16 .

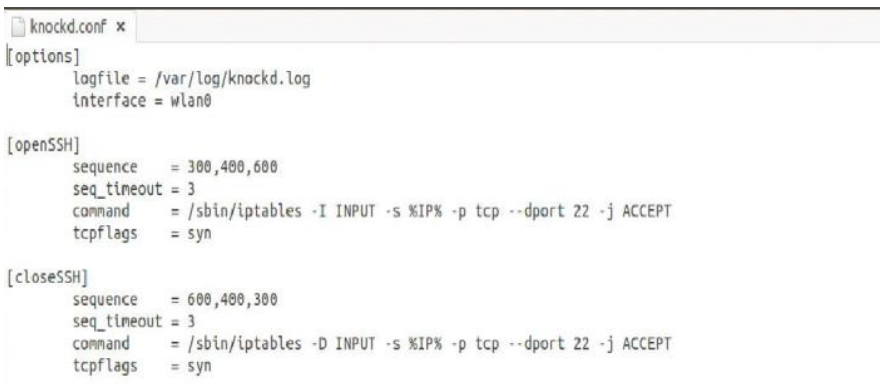

Gambar 16. File knockd.conf setelah dikonfigurasi

Setelah semua konfigurasi selesai, Jalankan aplikasi port knocking di server dengan mengetikkan perintah knockd $-D$. Seperti di tujunjukan pada gambar 17 .

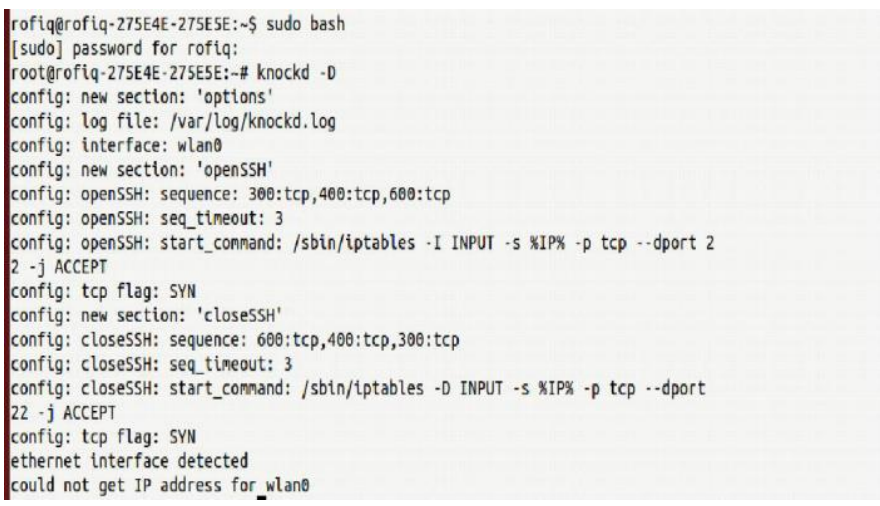

Gambar 17. Aplikasi knockd
Gambar 17 adalah tampilan aplikasi knockd setelah di aktifkan tampilan gambar tersebut mengacu pada isi file knockd.conf dan menggunakan wlan0 sebagai interfacesnya. Untuk melihat Ip address client yang melakukan koneksi ke server dapat dilihat dengan menggunakan perintah "gedit /var/log/knockd.log". hasilnya dapat dilihat pada gambar 18 .

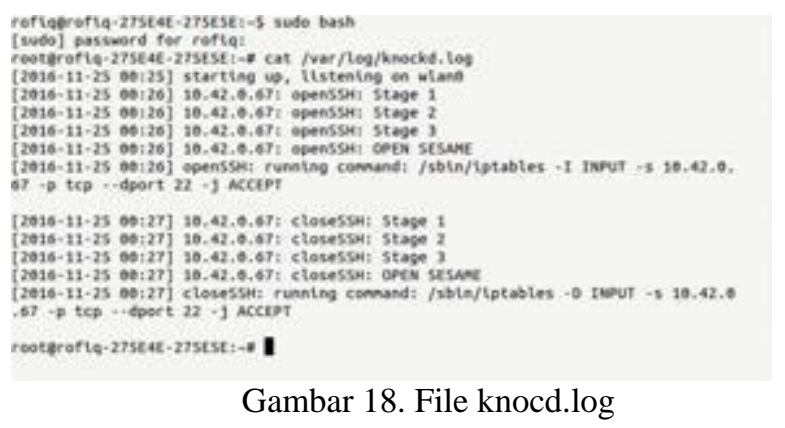

Pada gambar 18 dijelaskan bahwa pada tanggal 25 -11-2016 jam 00:26 dengan interface wlano membuka port 22 dan pada tanggal 25-11-2016 jam 00:27 menutup layanan ssh yang bejalan pada port 22 .

3.2 Scanning Port Tanpa Port Knocking

Pengujian scanning port dilakukan pada kondisi server tanpa menerapkan metode port knocking untuk mengetahui service atau layanan apa saja yang ada di server serta berjalan di port berapa saja, Pengujian ini di lakukan pada server sebelum menggunakan metode port knocking, Dalam pengujian scanning port menggunakan aplikasi scanning port.

Dalam pengujian pada penelitian ini memanfaatkan aplikasi nmap guna menemukan layanan pada server dan berjalan pada port berapa. Lebih jelasnya lihat gambar 19 .

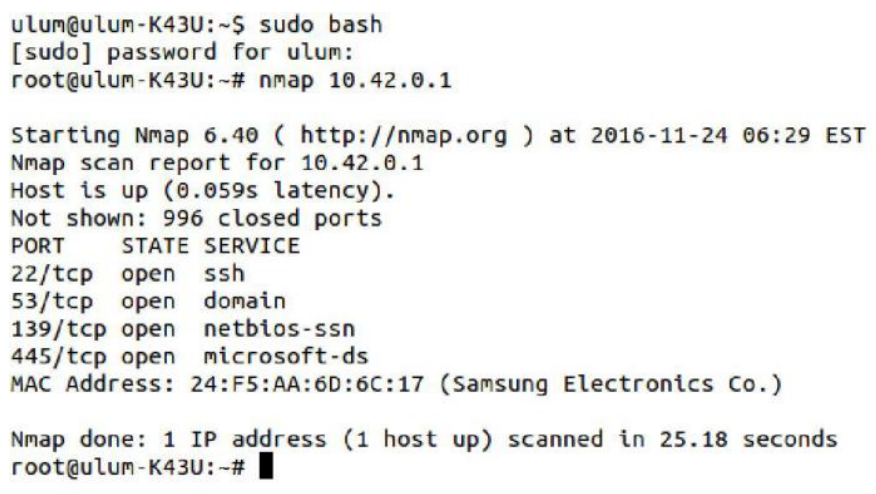

Gambar 19. Scanning port tanpa metode port knocking

Dari hasil gambar 19 dapat dijelaskan scanning port menggunakan nmap dapat menemukan layanan SSH pada port 22 yang ada di server dalam kondisi terbuka serta nmap dapat membaca operating system yang di gunakan server yang tanpa menggunakan metode port knocking. 


\subsection{Scanning Port Dengan Port Knocking}

Pengujian scanning port dilakukan pada kondisi server menggunakan metode port knocking untuk mengetahui service atau layanan apa saja yang ada di server serta berjalan di port berapa saja, Pengujian iini di lakukan pada server sebelum menggunakan metode port knocking.

Pengujian scanning port menggunakan Nmap yang di lakukan pada server dalam kondisi menggunakn metode port knocking untuk mengetahui apakah Nmap masih bisa menemukan service atau layanan pada server.

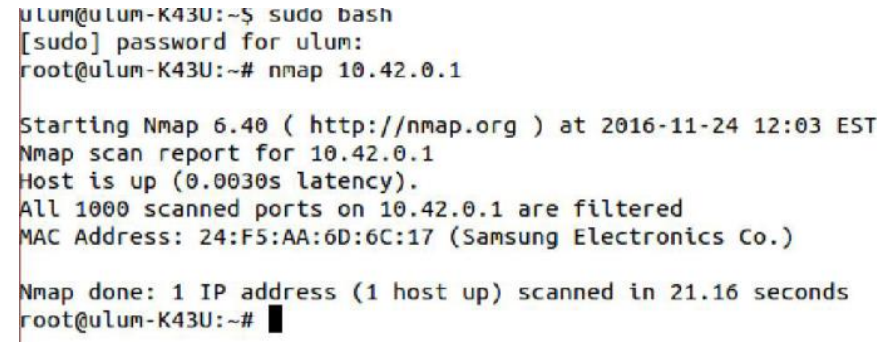

Gambar 20. Scanning port dengan metode port knocking

Dari hasil gambar 20 dapat dijelaskan setelah melakukan scanning port dengan menggunakan Nmap pada server menggunakan metode port knocking dengan status filtered.

\subsection{Pengujian Koneksi}

Pengujian koneksi dilakukan untuk mengetahui apakah sistem port knocking yang berjalan di server sesuai dengan rule atau aturan yang yang sudah ditetapkan pada aplikasi knockd.

3.4.1 Pengujian Koneksi Langsung

Pada pengujian ini dilakukan dengan cara melakukan percobaan koneksi koneksi langsung SSH dalam kondisi semua port menuju server di tutup oleh firewall ke server. Jelasnya bisa dilihat pada gambar 21.

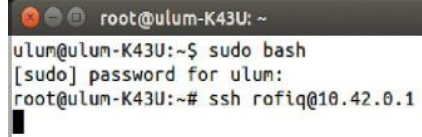

\section{Gambar 21. Koneksi langsung menuju server}

Pada gambar 21 dapat dijelaskan client melakukan koneksi ke server dengan kondisi semua port di tutup dengan menerapkan aturan DROOP aturan ini dimana semua koneksi yang melewati firewall dan tidak sesuai dengan aturan firewall akan langsung di blok tanpa memberi peringatan apapun

Pada pengujian yang kedua di mana client melakukan koneksi ke server untuk mengakses SSH yang berjalan di port 22 dengan kondisi server semua koneksi di tutup firewall dengan menggunakan aturan REJECT.

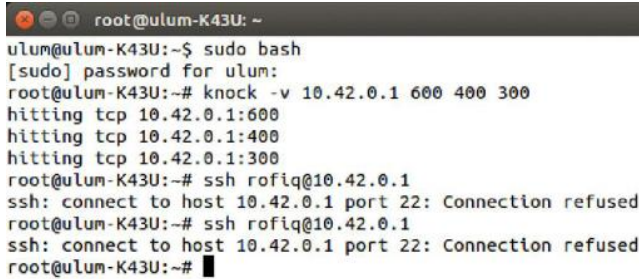

Gambar 22. Koneksi dengan aturan reject

Pada gambar 22 dapat di jelaskan di mana client melakukan koneksi ke server di blok oleh firewall dengan memberikan peringatan berupan CONECTION REFUSED.

\subsubsection{Pengujian Dengan Ketukan Yang Salah}

Pengujian koneksi yang dilakukan pada bahasan ini adalah untuk mengetahui bila ketukan yang dilakukan client salah atau berbeda dengan aturan yang di tetapkan pada port knocking, ataupun ketukan yang dilakukan kurang, misalnya pada rule port knocking menggunakan aturan ketukan tiga port dan client mengetuk dengan 2 port maka firewall tidak akan mengijinkan client tersebut mengakses SSH.

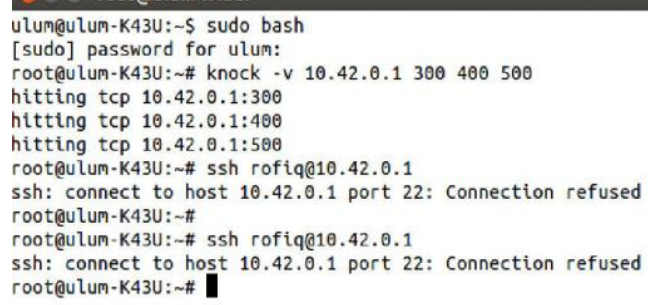

Gambar 23. Pengujian koneksi yang salah

Pada gambar 23 dapat dijelaskan client tidak dapat mengakses layanan SSH karena urutan ketukan yang di lakukan client tidak sesuai dengan rule yang ditetapkan pada firewall, Dalam koneksi tersebut client mengetuk port $300,400,500$ sedangkan rule yang ditetapkan adalah 300,400,600 sehingga client tidak di ijinkan oleh firewall untuk mengakses SSH.

\subsubsection{Pengujian Sesuai Aturan}

Pengujian yang dilakukan pada bahasan mengakses SSH sesuai dengan rule yang sudah ditetapkan pada port knocking misalnya: client dalam mengakses SSH dengan melakukan ketukan port pada port 300,400,600 sehingga client tersebut diijinkan mengakases SSH oleh firewall

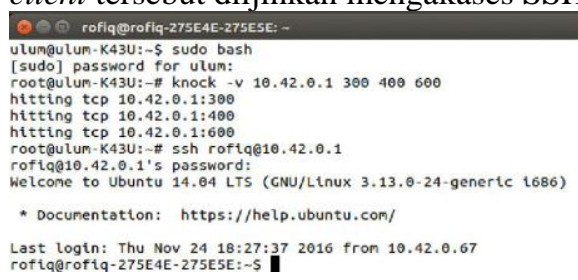

Gambar 24. Koneksi sesuai aturan 
Pada gambar di atas dapat di jelaskan client melakukan ketukan port sesuai dengan rule yang sudah ditetapkan sehingga client tersebut bisa mengakses layanan SSH.

3.4.4 Pengujian Koneksi Kembali

Pengujian pada bahasan ini menjelaskan setelah client berhasil mengakses layanan $\mathrm{SSH}$ dan setelah mengakhiri sesi koneksinya untuk melakukan koneksi kembali.

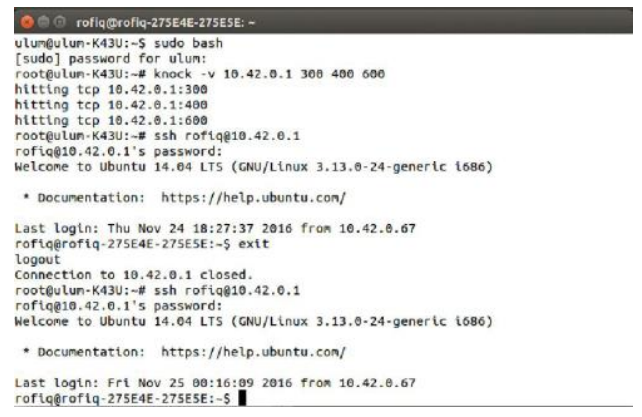

Gambar 25. Koneksi kembali normal

Pada gambar 25 client telah berhasil melakukan koneksi ke SSH yang bejalan pada port 22 dan setelah itu client keluar dari SSH. Client masih bisa mengakses SSH kembali tanpa melakukan ketukan sebelumnya, Karena Ip adress client masih berada dalam list IPTABLES.

\section{KESIMPULAN}

Berdasarkan kegiatan penelitian yang telah penulis lakukan terkait metode port knocking, maka ada beberapa kesimpulan yang dapat diambil, diantaranya adalah :

1. Sistem yang rancang telah mampu untuk menambah keamanan dalam proses autentikasi ke server, karena port tidak terbuka secara bebas ke publik.

2. Port knocking dapat mencegah penyerang dari pemindai sistem seperti service SSH dengan melakukan port scanning, sehingga service $\mathrm{SSH}$ tidak mudah dilacak dan diakses orang lain.

3. Metode port knocking untuk meningkatkan keamanan port SSH dapat menggunakan software free atau gratis yaitu knockd tanpa harus mengeluarkan biaya mahal dalam implementasinya terhadap sistem.

4. Metode port knocking dapat menambah keamanan disisi server karena client untuk mengakses SSH memerlukan sebuah ketukan port.

\section{SARAN}

Meningkatkan keamanan remote server menggunakan metode port knocking ini tentu tidak terlepas dari beberapa kekurangan. Oleh sebab itu, untuk pengembangan selanjutnya yang lebih baik, penulis menyarankan beberapa hal diantaranya adalah:

1. Sistem ini masih memanfaatkan program daemon yaitu knockd sehingga kalau daemon port knocking
2. mati server tidak dapat di akses karena tertutup oleh firewall.

3. Perlu adanya proses enkripsi untuk mengamankan port-port yang dikirim oleh client.

4. Perlu adanya tambahan layanan di server tidak hanya remote server.

\section{DAFTAR PUSTAKA}

[1] Andri, Trismanto. 2015. Port knocking URL:http://mastopix.blogspot.co.id/2014/11/pengertianport-knocking-teknik-yang.html

[2] Edy Haryanto. 2013. Meningkatkan keamanan port ssh dengan metode port knocking menggunakan shorewall Pada sistem operasi linux, Sekolah Tinggi Manajemen Informatika Dan Komputer Amikom Yogyakarta Yogyakarta

[3] Firman, Cahaya, Putra. 2009. Rancang Bangun Sistem Keamanan Jaringan Komputer Dengan Menggunakan Metode Port Knocking. Universitas pembangunan nasional "veteran" Jawa timur

[4] Guna Darma "Simbol-simbol standar dalam penggambaran flowchart" 2016 http://tri s.staf.gunadarma.ac.id

[5] I, Komang, Hartawan, Wijaya. 2011. Implementasi Port Knocking Pada Sistem Keamanan Jaringan Dengan Menerapkan Algoritma Rsa (Rivest Shamir Adleman). Universitas pembangunan nasional "veteran" Jawa timur

[6] Krzywinski, Martin. Juli 2016, Port Knocking. URL:http://www.portknocking.org/view/about/summary

[7] Muhammad Saleh Hafizh Fajri, 2014. Analisa Port Knocking Pada Sistem Operasi Linux Ubuntu Server 12.04 LTS. Program Studi Teknik Informatika Jurusan Komputer Politeknik Caltex Riau

[8] Oktaviani. 2007. Mengenal sistem firewall. Universitas Guna Darma.

[9] Rois, Awang, Rimbayani. 2013. Perncangan dan Implementasi Autentikasi Remote Server Dengan Menggunakan Metode Port Knocking Berbasis Loadable Kernel Module. Universitas Islam Negri Sunan Kalijaga Yogyakarta.

[10]Rio Handicha. 2009. Pengertian Dan Manfaat Memakai SSH. Di ambil 10 Oktober 2015 dari URL:http://riohandicha.blogspot.co.id/2014/06/pengerti an-dan-manfaat-memakai-ssh.html

[11]Syarif, Muhar. 2007-2008, Implementasi IPTABLES sebagai Filtering Firewall. Teknik Informatika Billingual, Fakultas Ilmu Komputer, Universitas Sriwijaya

[12]Verysson. Juli 2016. Cara kerja port knocking. URL:http//:cara kerja port knocking_verrysoon blog's.com

[13]WAHYU PURNAMA, 2014. Perancangan Sistem Pengamanan Akses Otentikasi Menggunakan Metode Port Knocking Dan Firewall Action Tarpit Pada Mikrotik Rb951-2n. Sekolah Tinggi Manajemen Informatika Dan Komputer Amikom Yogyakarta. 